\author{
V.P. Kvasnikov, S.V. Yehorov, T.Yu. Shkvarnytska \\ National Aviation University, Kyiv, Ukraine \\ (E-mail:kvp@nau.edu.ua, sehorov@gmail.com,tetyanashkvarnytska@gmail.com)
}

\title{
Technology for restoring functional dependencies to determine reliability parameters
}

\begin{abstract}
The problem of determining the properties of the object by analyzing the numerical and qualitative characteristics of a discrete sample is considered. A method has been developed to determine the probability of trouble-free operation of electronic systems for the case if the interpolation fields are different between several interpolation nodes. A method has been developed to determine the probability of trouble-free operation if the interpolation polynomial is the same for the entire interpolation domain. It is shown that local interpolation methods give more accurate results, in contrast to global interpolation methods. It is shown that in the case of global interpolation it is possible to determine the value of the function outside the given values by extrapolation methods, which makes it possible to predict the probability of failure. It is shown that the use of approximation methods to determine the probability of trouble-free operation reduces the error of the second kind. A method for analyzing the qualitative characteristics of functional dependences has been developed, which allows us to choose the optimal interpolation polynomial. With sufficient statistics, using the criteria of consent, it is possible to build mathematical models for the analysis of failure statistics of electronic equipment. Provided that the volume of statistics is not large, such statistics may not be sufficient and the application of consent criteria will lead to unsatisfactory results. Another approach is to use an approximation method that is applied to statistical material that was collected during testing or controlled operation. In this regard, it is extremely important to develop a method for determining the reliability of electronic systems in case of insufficiency of the collected statistics of failures of electronic equipment.
\end{abstract}

Keywords: approximation, interpolation, reliability of electronic equipment, statistical processing, restoration of functional dependence, estimation of reliability indicators, small sample, sufficiency of statistics.

\section{Introduction}

In order to increase the reliability and noise immunity of electronic systems operated in space and aviation, it is necessary to conduct numerical tests with high accuracy.

If it was possible to collect sufficient statistics, then using the criteria of agreement there is an opportunity to choose a mathematical apparatus with which you can analyze this series. But if the volume of statistics is not large, then such statistics may not be sufficient and the application of the consent criteria will lead to unsatisfactory results. The existing methods of studying the reliability of electronic equipment do not fully meet the requirements of practice and the level of production technology. It is explained by the fact that the values of real reliability indicators differ significantly from the forecast estimates, as the sufficiency of the collected statistics of failures is not taken into account.

Insufficient statistics make it impossible to apply the criteria of consent for the choice of the law of distribution of work to failure due to the large error of the second kind, with which the selected laws of distribution will align the collected statistics. Therefore, it is necessary to develop a method of data processing to study and solve this problem.

All of the above-mentioned leads to the need to solve the problem of restoring functional dependencies. Therefore, the problem of restoring functional dependences on a discrete experimentally obtained sample by local and global interpolation methods is relevant. Electronic systems are known to be highly reliable, and failure statistics are very difficult to collect. In the well-known publications of X. Changhui, R. Xiaoping, S. Xianfeng, G. Jingxiang on the study of reliability in [1] the modeling of the studied object by Kalman filtering method is

\footnotetext{
${ }^{*}$ Corresponding author.

E-mail: sehorov@gmail.com
} 
offered. But in the case of modeling the behavior of electronic systems, this method can lead to large errors in the simulation results. This is due to the fact that the technology of manufacturing electronic systems is very complex. In the electronic system there are a lot of complex processes, which are very difficult or impossible to take into account. For example, the software environment for modeling the operation of electronic circuits NI Multisim, in the case of building complex electronic circuits may not correctly model the processes occurring in electronic equipment. According to its properties, the Kalman filter will return more accurate results only if the data are normal in the distribution. But research data will not necessarily have a normal distribution. Therefore, the method described in [1] for modeling the behavior of electronic systems should be used only in the case of justification of the use of normal distribution.

Z. Zhengcheng, B. Narayanaswamy in [2] suggest determining of the probability of failure-free operation of the system using signatures, which are a function, the arguments of which are the operating time for failure. But the suggested method does not answer the question of the sufficiency of the collected statistics. H. Zhipeng, G. Jianbin, Z. Shengkui in [3] used a combination of Bayesian methods with system state vectors to determine the reliability of the system to reduce the number of calculations and the amount of statistics. But to determine the probability of failure, it cannot be recommended because the study [3] does not contain the calculation of the error that occurs if selected for data processing of a mathematical apparatus. F. Hailin, D. Jieyu in [4] suggests determining of the probability of failure-free operation of the system using signatures, as well as in [2], but the method suggested in [4] is suitable for solving problems of diagnosing and identifying problematic places during system operation.

S. Xujun, L. Xuezhi in [5] proposed on the basis of modeling of discrete events algorithm of modeling of reliability of system of a step-by-step mission with several states. The program algorithm includes the Markov process. But the degradation process that takes place in the system will not necessarily be Markov. Therefore, the reliability model for different types of systems will be individual.

Groezinger, A. Zimmermann in their research [6] tested the reliability of LEDs in the laboratory. A correlation analysis was used to process the test results. The presence of a correlation indicates the relationship between the data being analyzed, but does not determine the mathematical apparatus by which the experimental data can be processed. Of particular interest is the publication of X. Zhao, S. Wang, L. Sun [7] which suggested a method of planning tests for the reliability of finished products using Markov circles. However, in the production of complex electronic equipment, where it is necessary to control the parameters of the product at each stage of the technological cycle of production, this method is not suitable.

D. Zhou, H. Wang, F. Blaabjerg in [8] used the Weibull distribution to evaluate the reliability of mains electric filters and voltage converters and did not sufficiently substantiate their choice. For this reason, it is not known with what error the Weibull distribution will align the experimental data. In this case, it is necessary to check the plausibility of hypotheses and in case of insufficient statistics to solve the problem of restoring functional dependencies.

Kostanovsky V.V., Machalin I.A., Kozachuk O.D., Terentyeva I.A. in [9] have built a generalized probabilistic physical model of reliability of a two-level active phased array. Exponential and diffusion nonmonotonic distribution were used in [9] as models of failures of electronic components and transmission channels. However, [10] showed that the exponential and diffusion nonmonotonic distribution has no advantages along with other distributions with similar characteristics. Therefore, the use of exponential and diffusion nonmonotonic distribution in the study [9] is not justified.

Analysis of the literature [1-10] shows that the problem of restoring functional dependences on a discrete experimentally obtained sample by local and global interpolation methods is relevant.

Problem setting. It is necessary to develop a method of restoration of functional dependences in the conditions of insufficiency of statistical data by means of technologies of approximation and interpolation.

In order to achieve this goal, the following tasks were set:

- to investigate the existing methods of approximation;

- on the basis of research to develop a method for determining the probability of failure-free operation in case of insufficiency of statistics on a discrete experimentally obtained sample.

\section{Material and method}

At the first stage of data processing it is necessary to determine the sufficiency of statistics. This should be done according to the method described in [10]. If the statistics are insufficient, there are two options for solving this problem: 1 . Continue to collect failure statistics, in the case of actual observations, or simulate more failures. 2. Restoration of functional dependences by approximation methods. Suppose the values of some function at 
given points are known. You need to find intermediate values of this function, according to the approximation method. This is a task to restore the function. In addition, when performing calculations, it is convenient to replace complex functions with algebraic polynomials or other elementary functions, which are quite simple to calculate (problems on the approximation of the function) [11].

The formulation of the interpolation problem is as follows. In the interval $[a, b]$ the points $x_{i}, i=0,1, \ldots, N$ are given; $a \leq x_{i} \leq b$ and the value of the unknown function at these points $f_{i}, i=0,1, \ldots, N$. We need to find function $F(x)$ that takes the same values of $f_{i}$ at $x_{i}$. In this case, we look for $F(x)$ only on the segment $[a, b]$. If it is necessary to find a function outside the segment, then this is an extrapolation problem.

The problem has many solutions, because through the given points $\left(x_{i}, f_{i}\right), i=0,1, \ldots, N$, it is possible to draw infinitely many curves, each of which will be a graph of the function for which all interpolation conditions are fulfilled. The case of approximation of a function by polynomials is important for practice, [11]

$$
F(x)=a_{0}+a_{1} x+a_{2} x^{2}+\ldots+a_{m} x^{m} .
$$

All interpolation methods can be divided into local and global. In the case of local interpolation, a separate polynomial is constructed on each interval $\left[x_{i}{ }^{\lrcorner} 1, x_{i}\right]$. In the case of global interpolation, a single polynomial is found in the entire interval $[a, b]$.

On each segment $\left[x_{i \sim 1}, x_{i}\right]$ the interpolation polynomial is equal to a constant, namely the left or right value of the function.

For the left piecewise linear interpolation it is: $f(x)=f_{i-1}$, if i.e. $x_{i-1} \leq x<x_{i}[11,12]$

$$
F(x)=\left\{\begin{array}{l}
f_{0}, x_{0} \leq x<x_{1} \\
f_{1}, x_{1} \leq x<x_{2} \\
\cdots \\
f_{N-1}, x_{N-1} \leq x<x_{N} .
\end{array}\right.
$$

For the right piecewise linear interpolation it is: $F(x)=f_{i}$ if $x_{i-1}<x \leq x_{i}$, i.e. [11, 12].

$$
F(x)=\left\{\begin{array}{l}
f_{0}, x_{0}<x \leq x_{1} \\
f_{1}, x_{1}<x \leq x_{2} \\
\cdots \\
f_{N-1}, x_{N-1}<x \leq x_{N} .
\end{array}\right.
$$

Thus, the interpolation conditions are fulfilled. The constructed function is discontinuous, which limits its application.

The principle of piecewise-linear $[11,12]$ interpolation is as follows. At each interval $\left[x_{i-1}, x_{i}\right]$, the function is linear $F_{i}(x)=k_{i} x+l_{i}$. The values of the coefficients are from the fulfillment of the interpolation conditions at the ends of the segment: $f_{i}\left(x_{i-1}\right)=f_{i-1}, f_{i}\left(x_{i}\right)=f_{i}$. We get a system of equations: $k_{i} x_{i}+l_{i}=f_{i-1}$, where we find: $k_{i}=\frac{f_{i}-f_{i-1}}{x_{i}-x_{i-1}}, l_{i}=f_{i}-k_{i} x_{i}$ from. Therefore, the function $F(z)$ can be written as: $F(x)=\frac{f_{i}-f_{i-1}}{x_{i}-x_{i-1}} x+f_{i}-k_{i} x_{i}$ if $x_{i-1} \leq<x_{i}$ that is:

$$
F(x)=\left\{\begin{array}{l}
\frac{f_{1}-f_{0}}{x_{1}-x_{0}} x+f_{0}-k_{0} x_{0}, x_{0} \leq x_{i}<x_{1} \\
\frac{f_{2}-f_{1}}{x_{2}-x_{1}} x+f_{1}-k_{1} x_{1}, x_{1} \leq x_{1}<x_{2} \\
\cdots \\
\frac{f_{N}-f_{N-1}}{x_{N}-x_{N-1}} x+f_{N-1}-k_{N-1} x_{N-1}, x_{N-1} \leq x_{N-1}<x_{N} .
\end{array}\right.
$$

When using linear interpolation, you must first determine the interval in which the value of $\mathrm{x}$ falls, and then substitute it into the formula. The final function will be continuous, but the original derivative will be absent in each interpolation node. The error of such interpolation will be less than in the case of piecewise constant interpolation.

When interpolating functions, the condition of equality of values of interpolation polynomial and this function in interpolation nodes was used. If the original data are obtained as a result of experimental measurements, 
the requirement of exact coincidence, as a rule, does not apply because the data are not obtained accurately. In these cases, only an approximate fulfillment of the interpolation conditions can be required $\left.\mid F\left(x_{i}\right)-f\left(x_{i}\right)\right) \mid<\varepsilon$. This condition means that the interpolating function $\mathrm{F}(\mathrm{x})$ does not pass exactly through given points, but in some of their margins.

In this case, use a selection of empirical functions. The construction of an empirical function consists of two stages: the selection of the form of this function $\phi\left(x, a_{0}, a_{1}, \ldots, a_{m}\right)$, which contains unknown parameters $a_{0}, a_{1}, \ldots, a_{m}$, and the determination of the best in some sense arguments of this function. The type of function is sometimes known for physical reasons (for an elastic medium, the relationship between stress and strain). Or the type of function is chosen for geometric reasons: the experimental points are plotted on a graph and the general form of the dependence is roughly guessed by comparing the obtained curve with the graphs of known functions. Success here is largely determined by the experience and intuition of the researcher.

The case of approximation of a function by polynomials is important for practice [11-15], i.e.

$$
F(x)=a_{0}+a_{1} x+a_{2} x^{2}+\ldots+a_{m} x^{m} .
$$

Once the type of empirical dependence is selected, the degree of proximity to the empirical data is determined using a minimum of the sum of the squares of the deviations of the calculated and experimental data.

Suppose that for the initial datax $x_{i}, f_{i}, i=1, \ldots, N$ (numbering is better to start with one), the type of empirical dependence is chosen: $\phi\left(x, a_{0}, a_{1}, \ldots, a_{m}\right)$ with unknown coefficients $a_{0}, a_{1}, \ldots, a_{m}$. We write the sum of the squares of the deviations between the calculated by empirical formula and given experimental data:

$$
S\left(a_{0}, a_{1}, \ldots, a_{m}\right)=\sum_{i=1}^{N}\left(\phi\left(x, a_{0}, a_{1}, \ldots, a_{m}\right)-f_{i}\right)^{2} .
$$

We will find arguments $a_{0}, a_{1}, \ldots, a_{m}$ from the condition of a minimum of function $S\left(a_{0}, a_{1}, \ldots, a_{m}\right)$. This is the least squares method (LSM).

It is known that at the point of minimum all partial derivatives from $S$ to $a_{0}, a_{1}, \ldots, a_{m}$ are equal to zero $[11,15]$ :

$$
\frac{d S}{d a_{0}}=0, \frac{d S}{d a_{1}}=0, \ldots, \frac{d S}{d a_{m}}=0
$$

Consider the application of the LSM for a particular case, widely used in practice. As an empirical function, consider a polynomial $[11,15]$

$$
\phi(x)=a_{0}+a_{1} x+a_{2} x^{2}+\ldots+a_{m} x_{i}^{m},
$$

Formula (1) for determining the sum of squares of deviations will take the form [11, 15]:

$$
S\left(a_{0}, a_{1}, \ldots, a_{m}\right)=\sum_{i=1}^{N}\left(a_{0}+a_{1} x+a_{2} x^{2}+\ldots+a_{m} x^{m}-f_{i}\right)^{2}
$$

Calculate the derivatives $[11,15]$ :

$$
\left\{\begin{array}{l}
\frac{d S}{d a_{0}}=2 \sum_{i=1}^{N}\left(a_{0}+a_{1} x+a_{2} x^{2}+\ldots+a_{m} x^{m}-f_{i}\right) \\
\frac{d S}{d a_{1}}=2 \sum_{i=1}^{N}\left(a_{0}+a_{1} x+a_{2} x^{2}+\ldots+a_{m} x^{m}-f_{i}\right) x_{i} \\
\cdots \\
\frac{d S}{d a_{m}}=2 \sum_{i=1}^{N}\left(a_{0}+a_{1} x+a_{2} x^{2}+\ldots+a_{m} x^{m}-f_{i}\right) x_{i}^{m} .
\end{array}\right.
$$

Equating these expressions to zero and collecting the coefficients for the unknowns, we obtain a system of linear equations $[11,15]$ : 


$$
\left\{\begin{array}{l}
N a_{0}+a_{1} \sum_{i=1}^{N} x_{i}+a_{2} \sum_{i=1}^{N} x_{i}^{2}+\ldots+a_{m} \sum_{i=1}^{N} x_{i}^{m}=\sum_{i=1}^{N} f_{i} \\
a_{0} \sum_{i=1}^{N} x_{i}+a_{1} \sum_{i=1}^{N} x_{i}^{2}+a_{2} \sum_{i=1}^{N} x_{i}^{3}+\ldots+a_{m} \sum_{i=1}^{N} x_{i}^{m+1}=\sum_{i=1}^{N} x_{i} f_{i} \\
\ldots \\
a_{0} \sum_{i=1}^{N} x_{i}^{m}+a_{1} \sum_{i=1}^{N} x_{i}^{m+1}+a_{2} \sum_{i=1}^{N} x_{i}^{m+2}+\ldots+a_{m} \sum_{i=1}^{N} x_{i}^{2 m}=\sum_{i=1}^{N} x_{i}^{m} f_{i} .
\end{array}\right.
$$

This system of equations is called normal and is used to find the coefficients $a_{0}, a_{1}, . . a_{m}$.

As a rule, several empirical dependencies are chosen. The LSM finds the coefficients of these dependences and among them find the best for the minimum amount of deviations.

\section{Results of the research of approximation methods}

Selection of empirical functions. The specified values of the failure function of the electronic system (Table 1).

Table. 1 shows that $N=6$. You need to find empirical dependences: linear $\rho 1=a_{0}+a_{1} x$, quadratic $\rho 2=a_{0}+a_{1} x+a_{2} x^{2}$, hyperbolic $\rho 3=a_{0} \frac{a_{1}}{x}$ by the LSM and choose among them the best for the smallest sum of squares of deviations.

The system of normal equations for linear dependence:

$$
\left\{\begin{array}{l}
N a_{0}+a_{1} \sum_{i=1}^{N} x_{i}=\sum_{i=1}^{N} f_{i} \\
a_{0} \sum_{i=1}^{N} x_{i}+a_{1} \sum_{i=1}^{N} x_{i}^{2}=\sum_{i=1}^{N} x_{i} f_{i}
\end{array}\right.
$$

T a b l e 1

The number of failures and the corresponding probabilities

\begin{tabular}{|c|c|c|c|c|c|c|}
\hline Parameters used in the calculations & $x_{0}$ & $x_{1}$ & $x_{2}$ & $x_{3}$ & $x_{4}$ & $x_{5}$ \\
\hline$x$ (number of failures) & 1 & 2 & 3 & 4 & 8 & 10 \\
\hline$f$ (statistical probability of failure-free operation) & 0,1 & 0,15 & 0,2 & 0,3 & 0,45 & 0,7 \\
\hline
\end{tabular}

Given that $N=6$, and solving a system of linear equations, we obtain $a_{0}=-0,25 ; a 1=175$. Given that $\mathrm{N}=6$, and solving a system of linear equations, we obtain . Thus, the linear dependence has the form $\rho 1=-0,25+175 x$ (Fig. 1).

Calculate the sum of the squares of the deviations: $s_{1}=\sum_{i=0}^{6}\left(a_{0}+a_{1} x-f_{i}\right)^{2}=2,63$. Consider the quadratic dependence. The system of normal equations has the form:

$$
\left\{\begin{array}{l}
6 a_{0}+a_{1} \sum_{i=1}^{6} x_{i}+a_{2} \sum_{i=1}^{6} x_{i}^{2}=\sum_{i=1}^{6} f_{i} \\
a_{0} \sum_{i=1}^{6} x_{i}+a_{1} \sum_{i=1}^{6} x_{i}^{2}+a_{2} \sum_{i=1}^{6} x_{i}^{3}=\sum_{i=1}^{6} x_{i} f_{i} \\
a_{0} \sum_{i=1}^{6} x_{i}^{2}+a_{1} \sum_{i=1}^{6} x_{i}^{3}+a_{2} \sum_{i=1}^{6} x_{i}^{4}=\sum_{i=1}^{6} x_{i}^{2} f_{i}
\end{array}\right.
$$

Solving simultaneous linear algebraic equations we obtain $a_{0}=-0,101 ; a_{1}=14,982 ; a_{2}=0,162$. Thus, the quadratic dependence has the form: $\rho 2=-0,101+14,982 x+0,162 x^{2}$. Calculate the sum of the squares of the deviations: $s_{2}=\sum_{i=0}^{6}\left(a_{0}+a_{1} x+a_{2} x_{i}^{2}-f_{i}\right)^{2}=2,234$. 


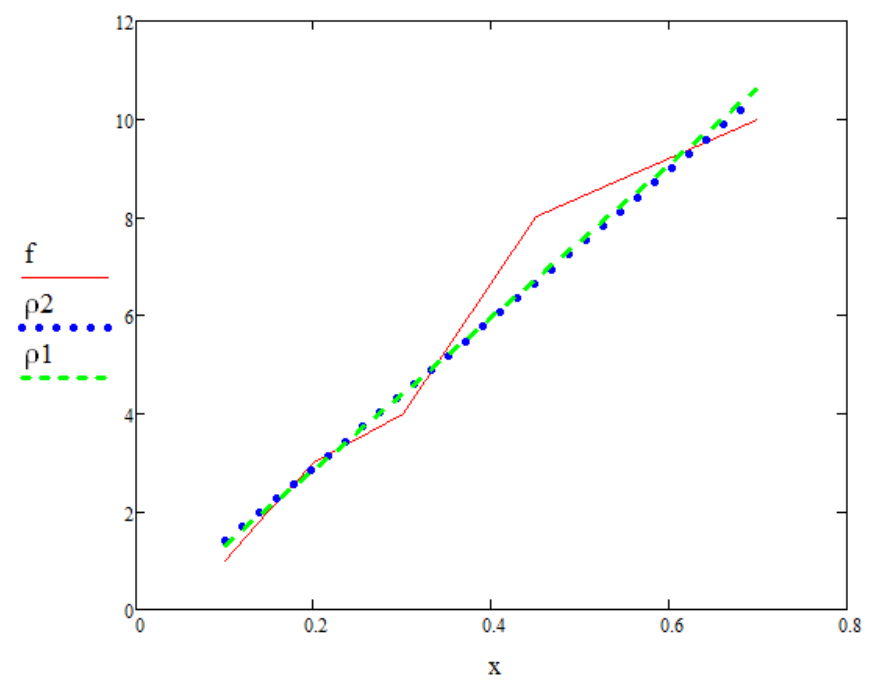

Figure 1. Approximation of experimental data by quadratic dependence: $f$ is the experimental data, $\rho 1$ - approximation by linear dependence, $\rho 2$ - approximation by quadratic dependence.

Let's make a system of normal equations for hyperbolic dependence. According to the LSM we find the sum of squares of deviations: $S_{3}=\sum_{i=0}^{N}\left(a_{0}+\frac{a_{1}}{x_{i}}-f_{i}\right)^{2}$. We make a system of normal equations:

$$
\left\{\begin{array}{l}
\frac{d S}{d a_{0}}=2 s_{3}=\sum_{i=1}^{6}\left(a_{0}+\frac{a_{1}}{x_{x_{i}}}-f_{i}\right)=0 \\
\frac{d S}{d a_{0}}=2 s_{3}=\sum_{i=1}^{6}\left(a_{0}+\frac{a_{1}}{x_{x_{i}}}-f_{i}\right) \frac{1}{x_{i}}=0 .
\end{array}\right.
$$

Solving the equations gives

$$
a_{0}=1,942 ; a 1=0,571 .
$$

The sum of deviations squares $S_{3}=-46,687$. Thus, the results of the calculations by the LSM show that it is best to approximate the curve by the quadratic dependence (Fig. 1).

As can be seen from Fig. 1 approximating curves $\rho 1$ and $\rho 2$ in appearance, in this case, it is very difficult to distinguish and very difficult to see which curve is better to approximate the experimental data. Therefore, it is very important to calculate the sum of the squares of the deviations.

\section{Conclusions}

As can be seen from Fig. 1 approximating curves describe a statistical series consisting of experimental data with some error. This error is characterized by the least squares check. In Fig. 1 it is difficult to see. In order to obtain more accurate results, it is necessary to use approximating curves of higher order, or local interpolation methods. The peculiarity of this method is that in the conditions of insufficiency of the collected statistics the probability of making an error of the second kind decreases due to the possibility to choose an approximating curve that can align the statistical series with the required accuracy. Analyzing the results of the research, it can be stated that the suggested method allows to effectively calculate the parameters of reliability in case of insufficiency of the collected statistics of failures.

The advantages of the suggested method are the following ones:

- it is possible to calculate the value of a function for any argument in short time with the required accuracy.

The disadvantages are:

- insufficient clarity in terms of the behavior of functional dependence;

- the analytical formula is often unknown;

- in some cases, the known functional dependence is too tedious for easy use in practice. 
But it should be noted that the disadvantages of the suggested method can be offset by the use of modern software and sufficiently powerful computer systems.

Due to the advent of computing systems that can handle multiple threads simultaneously, the prospect of developing approximation methods is the development of new methods for approximating numerical information with a multithreaded structure to solve problems in mathematical physics, such as grids, finite elements.

\section{References}

1 Changhui X. Generalized reliability measures of Kalman filtering for precise point positioning / X. Changhui, R. Xiaoping, S. Xianfeng, G.Jingxiang // Journal of Systems Engineering and Electronics. - 2013. - Vol. 24. - Issue 4. - P. 699-705. doi: 10.1109/JSEE.2013.00081

2 Zhengcheng Z. Representations for reliability functions of conditional coherent systems with INID components and ordered properties / Z.Zhengcheng, B. Narayanaswamy // Journal of Systems Engineering and Electronics. - 2015. - Vol. 26. - Issue 6. - P. 1316-1324. doi: 10.1109/JSEE.2015.

00144

3 Zhipeng H. Fully Bayesian reliability assessment of multi-state systems with overlapping data / H. Zhipeng, G. Jianbin, Z. Shengkui // Journal of Systems Engineering and Electronics. - 2017. - Vol. 28. Issue 1. - P. 187-198. doi: 10.21629/JSEE.2017.01.21

4 Hailin F. Reliability analysis for WSN based on a modular k-out-of-n system / F. Hailin, D. Jieyu // Journal of Systems Engineering and Electronics. - 2017. - Vol. 28. - Issue 2. - P. 407-412. doi: 10.21629/JSEE.2017.02.21

5 Xujun S. Reliability simulation and analysis of phased-mission system with multiple states / S. Xujun, L. Xuezhi // Journal of Systems Engineering and Electronics. - 2019. - Vol. 30. - Issue 3. - P. 624-632. doi: 10.21629/JSEE.2019.03.19

6 Soltani M. Reliability Study and Thermal Performance of LEDs on Molded Interconnect Devices (MID) and PCB / M. Soltani, M. Freyburger, R.Kulkarni, R. Mohr, T. Groezinger, A. Zimmermann // IEEE Access. - 2018. - Vol. 6. - P. 51669-51679. doi: ACCESS.2018.2869017

7 Zhao X. Single and Sequential Sampling Plans for Multi-Attribute Products and Multi-Class Lot in Reliability Test [Text] / X. Zhao, S. Wang, L. Sun // IEEE Access. - 2019. - Vol. 7. - P. 81145-81155. doi: 10.1109/ACCESS.2019.2923316

8 Zhou D. Mission Profile Based System-Level Reliability Analysis of DC/DC Converters for a Backup Power Application [Text] / D. Zhou, H. Wang, F.Blaabjerg // IEEE Transactions on Power Electronics. - 2018. - Vol. 33. - Issue 9. - P. 8030-8039. doi: TPEL.2017.2769161

9 Костановский В.В. Построение обобщенной вероятностно-физической модели надежности двухуровневой активной фазированной антенной решетки / В.В. Костановский, И.А. Мачалин, О.Д. Козачук, И.А. Терентьева // Восточно-Европейский журн. передовых технологий. - 2019. - Т. 3. - № 9 (99). - C. 31-40. doi: 10.15587/1729-4061.2019.168525

10 Єгоров С.В. Дослідження метода визначення безвідмовності технічних систем з використанням моделювання випробувань / С.В. Єгоров, Т.Ю. Шкварницька // Технологічний аудит та резерви виробництва. - 2016. - № 2/2(28). - С. 25-29. doi: 10.15587/2312-8372.2016.66481

11 Калиткин Н.Н. Численные методы / Н.Н. Калиткин. - СПб.: БХВ-Петербург, 2011. - 592 с.

12 Гусак А.А. Справочник по высшей математике / А.А. Гусак, Г.М. Гусак, Е.А. Бричикова. - Мн.: ТетраСистемс, 1999. - 640 с.

13 Анисимов-Спиридонов Д.Д. Методы и модели больших систем оптимального планирования и управления / Д.Д. Анисимов-Спиридонов. - М.: Наука, 1969. - 960 с.

14 Юдин Д.Б. Линейное программирование / Д.Б. Юдин, Е.Г. Гольштейн. - М.: Наука, 1969. - 424 с.

15 Венецкий И.Г. Основные математико-статистические понятия и формулы в экономическом анализе: справоч. / И.Г. Венецкий, В.И. Венецкая. - М.: Статистика, 1979. - 447 с. 


\title{
Сенімділік параметрлерін анықтау үшін функционалдық тәуелділікті қалпына келтіру технологиясы
}

\begin{abstract}
Дискретті іріктеу бойынша сандық және сапалық сипаттамаларды талдау арқылы объектінің қасиеттерін анықтау мәселесі қарастырылды. Интерполяцияның бірнеше түйіндері арасындағы интерполяциялық көпмүшелер әр түрлі болған жағдайда электронды жүйелердің ақаусыз жұмыс істеу ықтималдығын анықтау әдісі жасалды. Интерполяция полиномы интерполяцияның бүкіл ауданы үшін бірдей болған жағдайда, ақаусыз жұмыс ықтималдығын анықтау әдісі жасалды. Жергілікті интерполяция әдістері жаһандық интерполяция әдістеріне қарағанда дәлірек нәтиже беретіні көрсетілген. Ғаламдық интерполяция жағдайында экстраполяция әдістерімен берілген мәндерден тыс функцияның мәнін анықтауға болатындығы көрсетілген, бұл ақаусыз жұмыс ықтималдығын болжау мүмкіндігін береді. Ақаусыз жұмыс ықтималдығын анықтау үшін аппроксимациялау әдістерін қолдану екінші типтегі қателіктің төмендеуіне әкелетіндігі көрсетілген. Функционалды тәуелділіктердің сапалық сипаттамаларын талдау әдісі жасалды, бұл оңтайлы интерполяциялық көпмүшені таңдауға мүмкіндік береді. Жеткілікті статистикамен келісім критерийлерін қолдана отырып, электронды жабдықтың істен шығу статистикасын талдаудың математикалық модельдерін құруға болады. Егер статистика көлемі үлкен болмаса, онда мұндай статистика жеткіліксіз болуы мүмкін және келісім критерийлерін қолдану қанағаттанарлықсыз нәтижелерге әкеледі. Тағы бір тәсіл - тестілеу кезінде жиналған статистикалық материалға немесе бақыланатын пайдаланудағы материалға қолданылатын аппроксимациялау әдісін қолдану. Осыған байланысты электронды жабдықтың істен шығу статистикасы жеткіліксіз болған жағдайда электронды жүйелердің сенімділігін анықтау әдісін жасау өте маңызды.
\end{abstract}

Kiлm сөздер: электронды жабдықтың жақындауы, интерполяциясы, сенімділігі, статистикалық өңдеу, функционалды тәуелділікті қалпына келтіру, сенімділік көрсеткіштерін бағалау, шағын іріктеме, статистиканың жеткіліктілігі.

\author{
В.П. Квасников, С.В. Егоров, Т.Ю. Шкварницкая
}

\section{Технология восстановления функциональных зависимостей для определения параметров надёжности}

\begin{abstract}
Рассмотрена задача определения свойств объекта путём анализа числовых и качественных характеристик по дискретной выборке. Разработан метод определения вероятности безотказной работы электронных систем для случая, когда интерполяционные полиномы между несколькими узлами интерполяции различны. Разработан метод определения вероятности безотказной работы в случае, когда интерполяционный полином для всей области интерполяции одинаковый. Показано, что методы локальной интерполяции дают более точные результаты в отличие от методов глобальной интерполяции. Показано, что в случае глобальной интерполяции есть возможность определить значение функции за пределами заданных значений методами экстраполяции, что дает возможность прогнозирования вероятности безотказной работы. Показано, что использование методов аппроксимации для определения вероятности безотказной работы приводит к уменьшению ошибки второго рода. Разработан метод анализа качественных характеристик функциональных зависимостей, что позволяет выбирать оптимальный интерполяционный полином. При достаточной статистике, с использованием критериев согласия, можно строить математические модели анализа статистики отказов электронной аппаратуры. При условии, что объем статистики небольшой, такая статистика может оказаться недостаточной, и применение критериев согласия приведёт к неудовлетворительным результатам. Другой подход состоит в использовании метода аппроксимации, который применяется к статистическому материалу, который был собран во время испытаний, или подконтрольной эксплуатации. В связи с этим крайне важно разработать метод определения надежности электронных систем в случае недостаточности собранной статистики отказов электронной аппаратуры.
\end{abstract}

Ключевые слова: аппроксимация, интерполяция, надёжность электронной аппаратуры, статистическая обработка, восстановление функциональной зависимости, оценка показателей надёжности, малая выборка, достаточность статистики. 


\section{References}

1 Changhui, X., Xiaoping, R., Xianfeng, S., \& Jingxiang, G. (2013). Generalized reliability measures of Kalman filtering for precise point positioning. Journal of Systems Engineering and Electronics, 24(4), 699-705. DOI: 10.1109/JSEE.2013.00081

2 Zhengcheng, Z., \& Narayanaswamy, B. (2015). Representations for reliability functions of conditional coherent systems with INID components and ordered properties. Journal of Systems Engineering and Electronics, 26(6), 1316-1324. DOI: 10.1109/JSEE. 2015.00144

3 Zhipeng, H., Jianbin, G., \& Shengkui, Z. (2017). Fully Bayesian reliability assessment of multi-state systems with overlapping data. Journal of Systems Engineering and Electronics, 28(1), 187-198. DOI: 10.21629/JSEE.2017.01.21

4 Hailin, F., \& Jieyu, D. (2017). Reliability analysis for WSN based on a modular k-out-of-n system. Journal of Systems Engineering and Electronics, 28(2), 407-412. DOI: 10.21629/JSEE.2017.02.21

5 Xujun, S., \& Xuezh,i L. (2019). Reliability simulation and analysis of phased-mission system with multiple states. Journal of Systems Engineering and Electronics, 30(3), 624-632. DOI: 10.21629/JSEE.2019.03.19

6 Soltani, M., Freyburger, M., Kulkarni, R., Mohr, R., Groezinger, T., \& Zimmermann, A. (2018). Reliability Study and Thermal Performance of LEDs on Molded Interconnect Devices (MID) and PCB. IEEE Access, 6, 51669-51679. DOI: 10.1109/ACCESS.2018.2869017

7 Zhao, X., Wang, S., \& Sun, L. (2019). Single and Sequential Sampling Plans for Multi-Attribute Products and Multi-Class Lot in Reliability Test. IEEE Access, 7, 81145-81155.

DOI: 10.1109 /ACCESS.2019.2923316

8 Zhou, D., Wang, H., \& Blaabjerg, F. (2018). Mission Profile Based System-Level Reliability Analysis of DC/DC Converters for a Backup Power Application. IEEE Transactions on Power Electronics, 33(9), 8030-8039. DOI: 10.1109/TPEL.2017.2769161

9 Kostanovsky, V., Machalin, I., Kozachuk, O., \& Terentyeva, I. (2019). Construction of a generalized probabilistic-physical model of reliability of a two-level active phased antenna array. Eastern-European Journal of Enterprise Technologies, 3, 9(99), 31-40. DOI: 10.15587/1729-4061.2019.168525

10 Yehorov, S.V., \& Shkvarnytska, T.Yu. (2016). Research of method for determining reliability of technical system using simulation tests. Technology audit and production reserves, 2/2(28), 25-29. DOI: 10.15587 /2312-8372.2016.66481

11 Kalitkin, N.N. (2011). Chislennye metody [Numerical methods]. Saint Petersburg: BHV-Peterburg [in Russian].

12 Gusak, A.A., Gusak, G.M., \& Brichikova, E.A. (1999). Spravochnik po vysshei matematike [Handbook of Higher Mathematics]. Minsk: TetraSistems [in Russian].

13 Anisimov-Spiridonov, D. D. (1969). Metody i modeli bolshikh sistem optimalnoho planirovaniia $i$ upravleniia [Methods and models of large systems of optimal planning and control]. Moscow: Nauka [in Russian].

14 Yudin, D. B., \& Golshtejn, E. G. (1969). Lineinoe prohrammirovanie [Linear programming]. Moscow: Nauka [in Russian].

15 Veneckij, I.G., \& Veneckaya, V.I. (1979). Osnovnye matematiko-statisticheskie poniatiia $i$ formuly $v$ ekonomicheskom analize: spravochnik [Basic mathematical and statistical concepts and formulas in economic analysis: Handbook]. Moscow: Statistika [in Russian]. 